\title{
The Demographic Transition in Finland ${ }^{\star}$
}

\author{
by AARNO STRÖMMER
}

In this study, the results of Finnish research into the development of fertility, mortality and natural increase up to the present are brought together to form an integrated picture of the demographic transition in Finlands. At the same time, of course, an attempt is made to fill in and sharpen the outlines of those details of the picture which were, perhaps, earlier only roughly sketched.

Since it is concerned with the past, this may be described as a study in historical demography. However, it overlaps into other areas of demography for two reasons. In the first place, an important part is played by the analysis and regional charting of the present stage of development; secondly, the methods used here belong mainly to the field of formal demography or demometry.

This choice of methods is a clue to one of the goals of the study: to purify the picture of demographic development from the superficial effects of changes in the population structure.

In general, as the available statistical material improved, it was possible to use more and more sophisticated measuring devices.

* The article is based on the English summary of the author's dissertation, -Väestöllinen muuntuminen Suomessas (The demographic transition in Finland. An analytic description of the development and regional variation in the fertility, mortality and natural increase of the Finnish population 1722-1965). Publications of the Population Research Intitute, series A: 13 . Tornio 1969. 188 pp.

The dissertation was presented for public criticism on June 6th, 1969.
The analysis of the overall development for the whole country ${ }^{1}$ begins with the year 1722. For the pre-industrial period it is based more or less on the crude indicators of change - the crude rates of birth, death and natural increase. As far as the actual period of transition is concerned, mortality has been studied by calculating the so-called abridged life tables according to the method of Reed and Merrell for five-year periods, beginning with the period $1871-75$. Beginning with the same period, fertility has been studied by birth cohort, using the Ryder method (Problems of trend determination during a transition in Fertility. The Milbank Memorial Fund Quarterly. Vol. XXXIV, No. 1, Jan. 1956); this has been supplemented since 1938 by a year-by-year analysis of the marriage cohorts. The intrinsic rate of natural increase, based on the concept of the stable population developed by Lotka, as well as the reproduction rates, have also been calculated from the beginning of the 1870's.

1 The general development in the country as a whole is approached in three different sections. The first concerns the pre-industrial period, i.e. the population development up to 1870 , in the hope of discovering the possible roots in that period of the later transitional phenomena (Ch. 2). These phenomena themselves are discussed in two separate sections, the first of which concerns the early stages of industrialisation, i.e. the period from the 1870's to the 1930's (Ch. 3 ), while the second concentrates on the period from the 1930's to the present (Ch. 4). 


\section{Uusimaa}

2. Ahvenanmaa

3. Varsinais-Suomi

4. Satakunta

5. Tammermaa

6. Etelä-Häme

7. Kaakkois-Suomi

LK. Surrendered Carelia

8. Etelä-Savo

9. Pohjois-Karjala

10. Pohjois-Savo

11. Keski-Suomi

12. Etelä-Pohjanmaa

13. Keski-Pohjanmaa

14. Kainuu

15. Pohjois-Pohjanmaa

16. Lappi

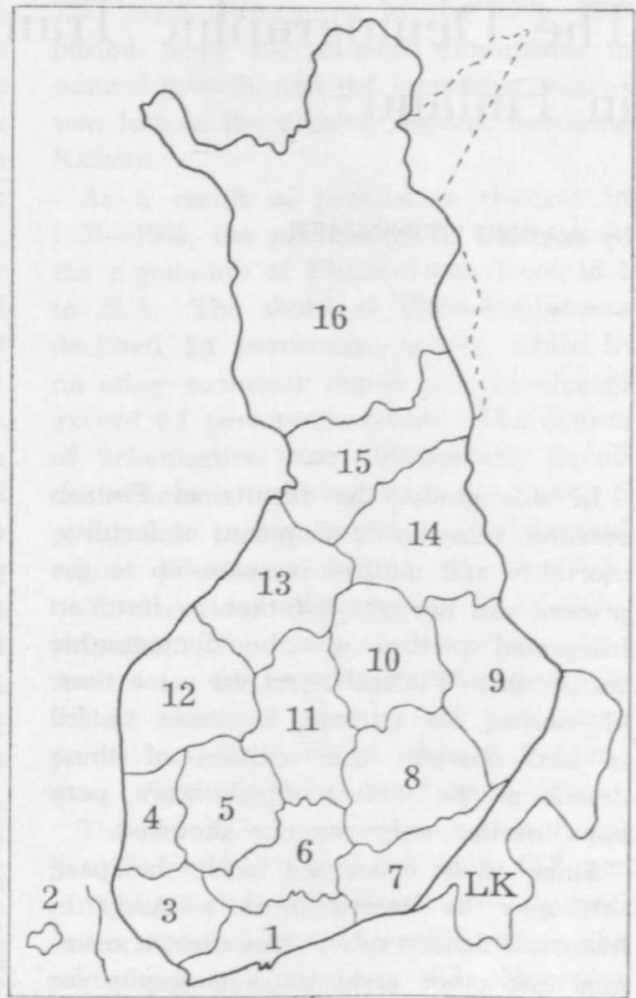

Figure 1. The regions of the study.

The regional process of transition ${ }^{1}$ has also had to be approached, in the earliest stages, on the basis of crude indicators. An effort, however, has been made to sharpen the picture by means of the available information on the changes in the population structure.

1 The study of regional variation (Ch. 5) has been concerned, on the one hand, with developmental differences between urban and rural areas, and on the other hand with the transition as it occurs in different parts of the country. Only the study of the most recent developments in fertility could be carried out commune-by-commune. Otherwise, the country was divided into 16 regions, the boundaries of which are shown in Fig. 1. These regions are identical with those used by the Finnish National Planning Bureau for its regional studies, and they have subsequently been adopted as statistical regions in the official Finnish statistics.
In comparing the development in the cities and in the country, more advanced fertility and mortality analyses have been feasible from the very beginning (187175 ), the latter in the form of standardized death rates calculated by the indirect method of standardization. In the comparison of situation and development in the various regions of the country, the use of more precise methods of measurement has been possible only on the basis of the general population censuses carried out in 1950 and 1960 . It should be observed that the differences in population structure between the various parts of the country have increased as a result of migration, even before the Second World War but especially since then. As a result, the use of measurements to eliminate the effect of structural differences in trying to obtain a spure, picture is even more essential. 
It is probably impossible to state conclusively, precisely when the period of transition in the overall demographic development of Finland began. Mortality among small children and in particular infant mortality (Fig. 2) began decreasing already in the 1700 's. The downward tendency of the crude death rate began in the 1880 's, after the overall fall following the famine years of $1866-68$ (Fig. 3) The crude birth rate, on the other hand, did not begin to decrease until after the turn of the century; the year 1910 forms a particularly clear threshold in the demographic development.

In the general picture of the demographic transition in Finland, no increase in the natural population growth rate can be discerned after 1880 . This is due to a kind of pre-threshold in the crude birth rate, preceding the main demographic threshold and brought about mainly by changes in the population structure. This pre-threshold occured around 1890 , when the small generations of the famine years began to found families, while overseas migration began at the same time to assume more significant proportions. The intrinsic rate of natural increase (Table A, col, 13), which removes the effect of structural changes from the picture of development, actually shows a very mild increase in the growth potential up to the 1910's. It should be stressed that the actual growth, in spite of everything, was quite large at the beginning of the transition period, since there were no more of the sblack years, of high mortality which were characteristic of the pre-industrial era.

The downward trend in mortality has continued up to today. The mean length of life rose between $1881-85$ and $1961-65$ from 41.1 to 65.5 years for men and from 43.8 to 72.7 years for women. The crude death rate has correspondingly fallen from 22.2 to 9.4 pro mille. The downward trend of the last measure is about to come to a halt; since the end of the 1950's the crude death rate has no longer decreased.

The crude birth rate decreased especially sharply after the demographic threshold, in spite of the fact that this development was retarded by changes in the age distribution, in this case by an increase in the relative number of women of child-bearing age. Another such brake was the sharp drop in the average age of mothers at childbirth, bringing about a piling-up of births at an earlier time

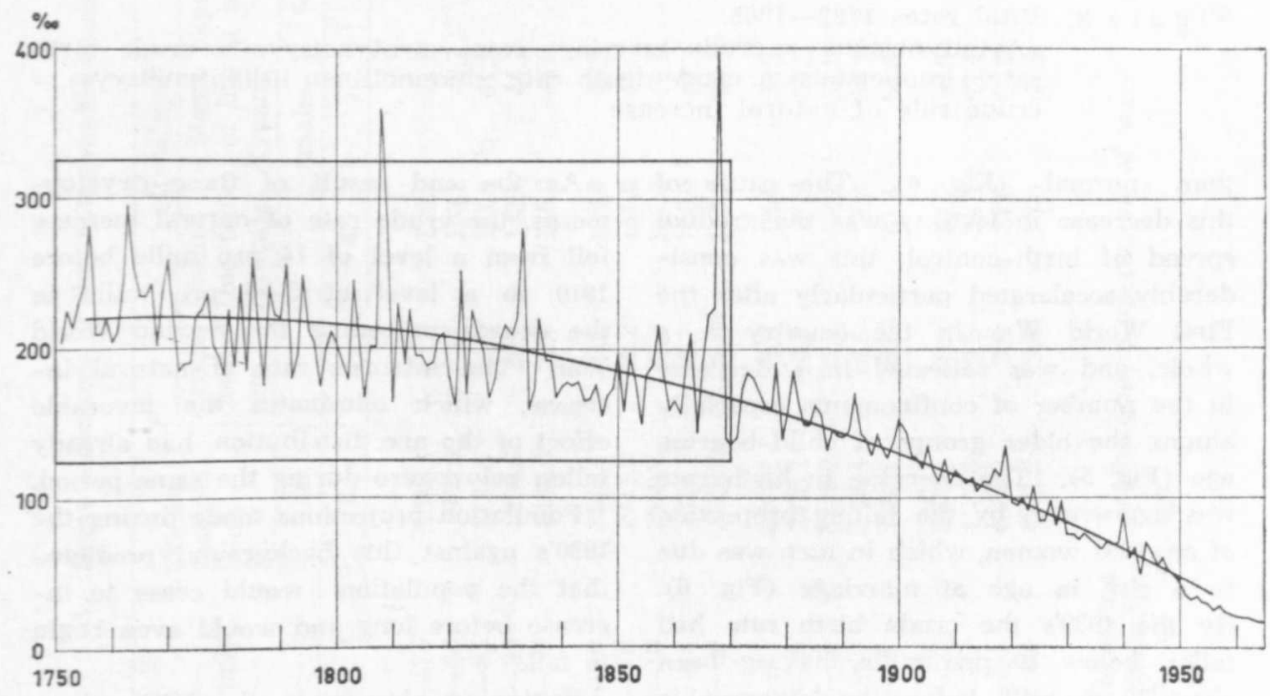

Figure 2. Infant mortality, 1750-1965. 
$\%$
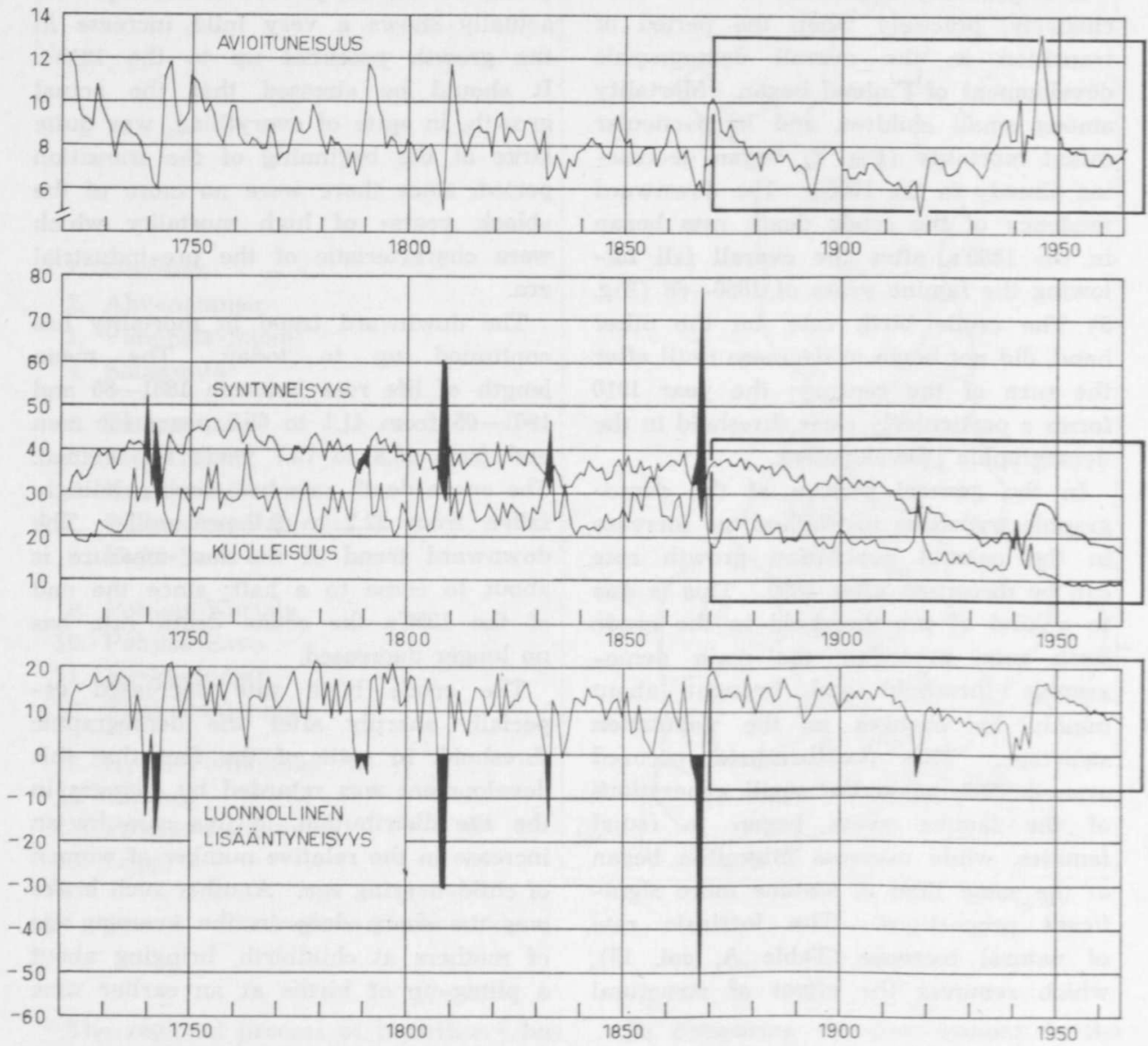

Figure 3. Vital rates $1722-1965$.

"Avioituneisuus» $=$ crude marriage rate, $»$ syntyneisyys $=$ crude birth rate, »kuolleisuus» = crude death rate, sluonnollinen lisääntyneisyys» = crude rate of natural increase.

than snormals (Fig. 4). The cause of this decrease in fertility was the gradual spread of birth-control; this was considerably accelerated particularly after the First World War in the country as a whole, and was reflected in a decrease in the number of confinements especially among the older groups of child-bearing age (Fig. 5). The decrease in birth rate was aggravated by the falling proportion of married women, which in turn was due to a rise in age at marriage (Fig. 6). By the 1930 's the crude birth rate had fallen below 20 pro mille, having been about 30 pro mille before the demographic threshold.
As the end result of these developments, the crude rate of natural increase fell from a level of 14 pro mille before 1910 to a level of 5-6 pro mille in the decade preceding the Second World War. The intrinsic rate of natural increase, which eliminates the favorable effect of the age distribution, had already fallen below zero during the same period.

Population projections made during the 1930's against this background predicted that the population would cease to increase before long and would even begin to fall.

Beginning already in the 1930's there was an upward turn in the crude mar- 


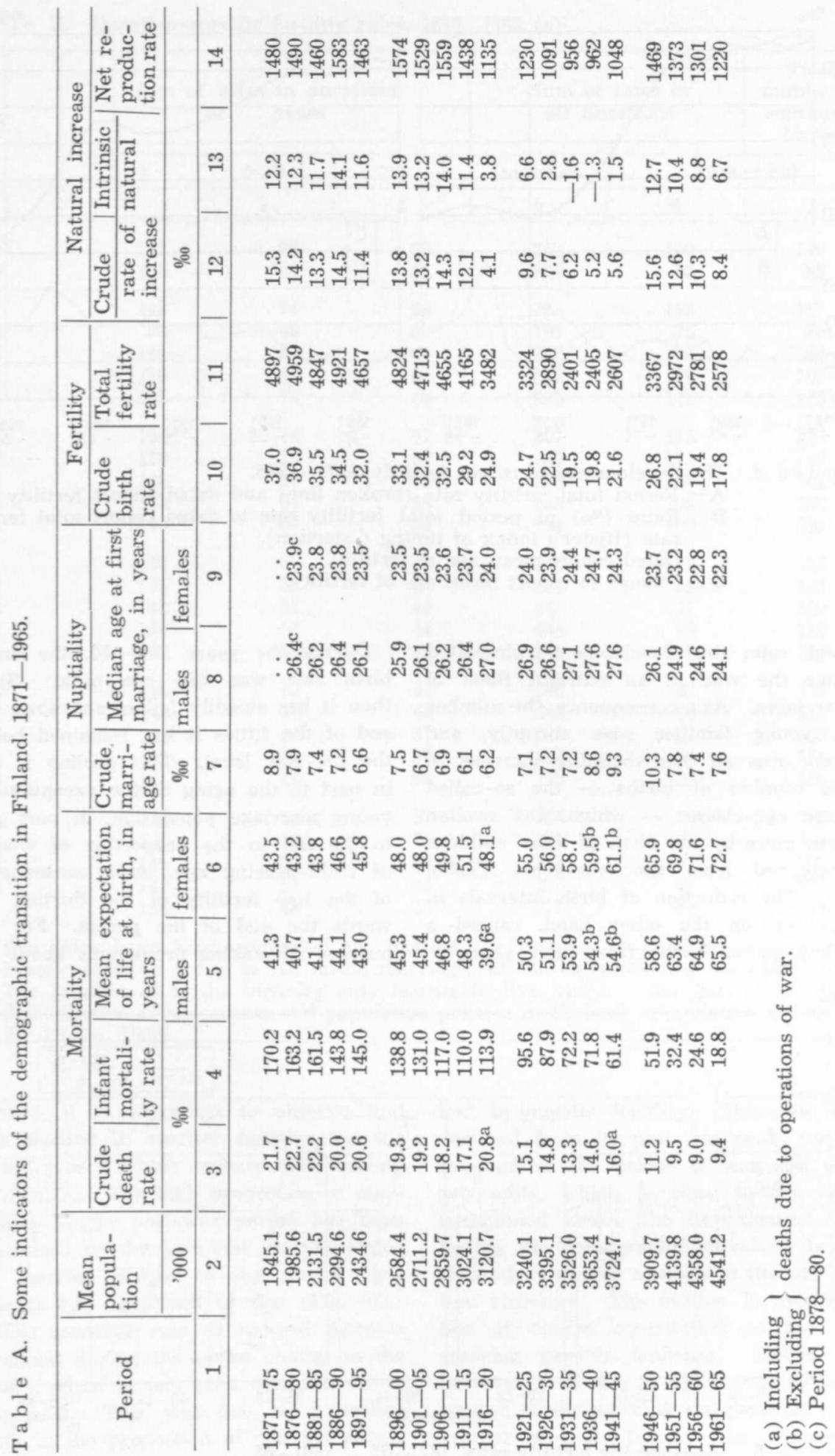



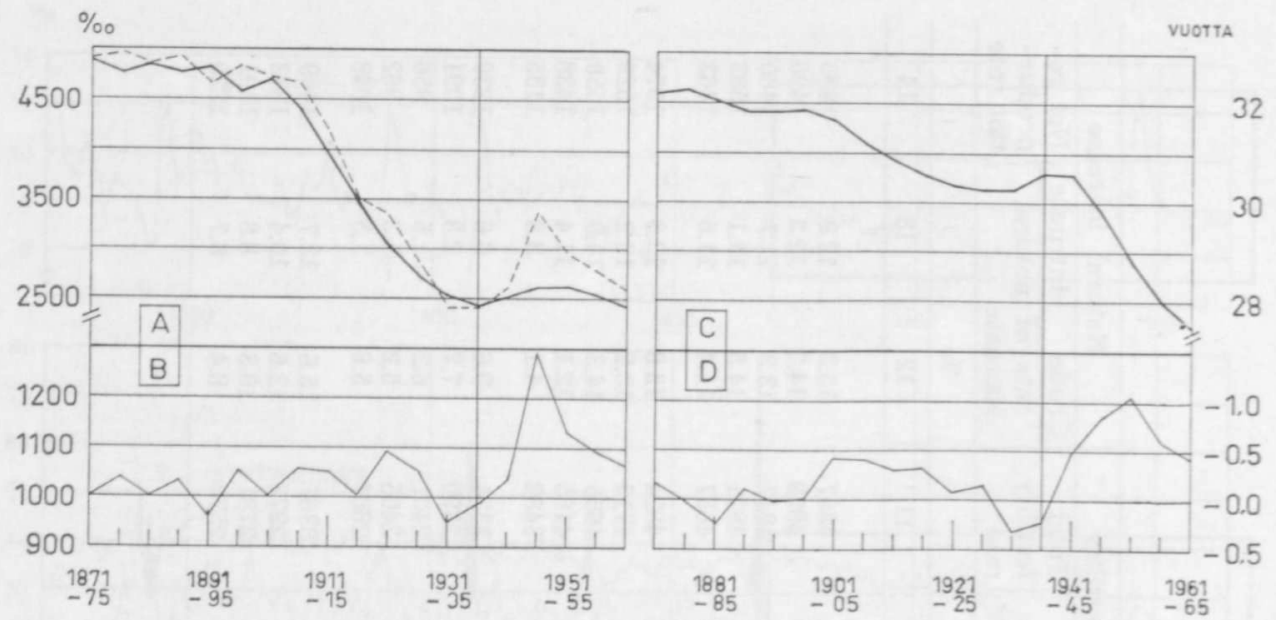

Figure 4. The development of cohort fertility, 1871-1965.

$\mathrm{A}=$ Period total fertility rate (broken line) and dated cohort fertility rate.

$\mathrm{B}=$ Ratio $(\%)$ of period total fertility rate to dated cohort total fertility rate (Ryder's index of timing distortion).

$\mathrm{C}=$ Dated cohort mean age of fertility.

$\mathrm{D}=$ Change in cohort mean age of fertility.

riage rate; this development culminated after the war in an outright flood of marriages. As a consequence, the number of young families rose abruptly, and there was an overwhelming increase in the number of births - the so-called large age-classes - which was swollen even more by the birth of those children postponed from the war-years (Table B). The reduction of birth intervals in families, on the other hand, caused a piling up of births from later years.
During the years $1946-50$, the crude birth rate was 26.8 pro mille. Since then it has steadily fallen, and since the end of the fifties it has remained below the pre-war level. This decline is due in part to the aging of the exceptionally young marriage population, in part also to the fall in the proportion of women of child-bearing age, as a consequence of the low fertility of the thirties, towards the end of the period. For the purpose of making predictions about the

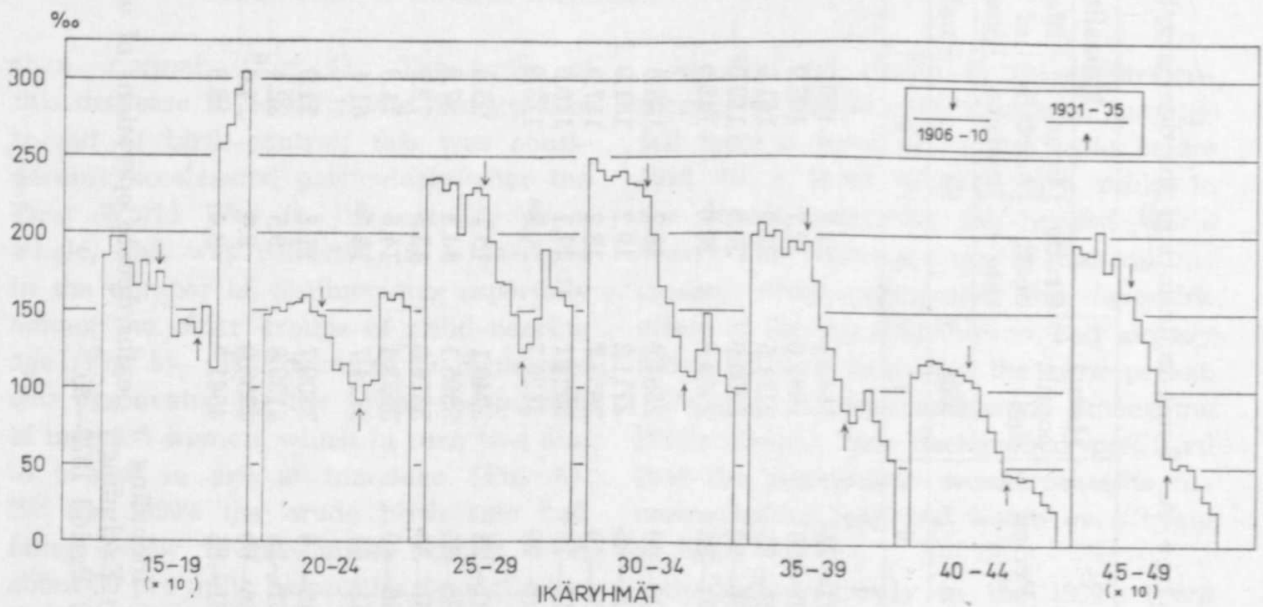

Fig ure 5. Age-specific fertility rates, $1871-75 \ldots$. 1961-65.

(sIkäryhmät: = age groups) 
Table B. Duration-specific fertility rates, 1939-1965 (a).

\begin{tabular}{|c|c|c|c|c|c|c|}
\hline \multirow{3}{*}{$\begin{array}{r}\text { Year } \\
\\
1 \\
\end{array}$} & \multicolumn{3}{|c|}{$\begin{array}{c}\text { Sum of rates in durations } \\
\text { of } \ldots \text { years }\end{array}$} & \multicolumn{2}{|c|}{$\begin{array}{l}\text { Sum of rates in } \\
\text { all durations }\end{array}$} & \multirow{2}{*}{$\begin{array}{c}\text { Total } \\
\text { number of } \\
\text { legitimate } \\
\text { births }\end{array}$} \\
\hline & $0-4$ & $5-9$ & $10-$ & number & & \\
\hline & 2 & 3 & 4 & 5 & 6 & 7 \\
\hline $\begin{array}{l}1939 \\
1940\end{array}$ & $\begin{array}{l}131 \\
105\end{array}$ & $\begin{array}{l}63 \\
51\end{array}$ & $\begin{array}{l}58 \\
51\end{array}$ & $\begin{array}{l}252 \\
207\end{array}$ & $\begin{array}{r}100 \\
82\end{array}$ & $\begin{array}{r}100 \\
83\end{array}$ \\
\hline $\begin{array}{l}1941 \\
1942 \\
1943 \\
1944 \\
1945\end{array}$ & $\begin{array}{r}143 \\
92 \\
111 \\
118 \\
145\end{array}$ & $\begin{array}{l}74 \\
49 \\
62 \\
62 \\
73\end{array}$ & $\begin{array}{l}68 \\
50 \\
66 \\
62 \\
65\end{array}$ & $\begin{array}{l}285 \\
191 \\
239 \\
242 \\
283\end{array}$ & $\begin{array}{r}113 \\
75 \\
94 \\
96 \\
112 \\
\end{array}$ & $\begin{array}{r}117 \\
80 \\
99 \\
102 \\
123\end{array}$ \\
\hline $\begin{array}{l}1946 \\
1947 \\
1948 \\
1949 \\
1950\end{array}$ & $\begin{array}{l}150 \\
150 \\
149 \\
143 \\
140\end{array}$ & $\begin{array}{l}74 \\
70 \\
67 \\
64 \\
60\end{array}$ & $\begin{array}{l}67 \\
62 \\
60 \\
58 \\
54\end{array}$ & $\begin{array}{l}291 \\
282 \\
276 \\
265 \\
254\end{array}$ & $\begin{array}{l}115 \\
111 \\
109 \\
105 \\
100\end{array}$ & $\begin{array}{l}138 \\
142 \\
141 \\
136 \\
129\end{array}$ \\
\hline $\begin{array}{l}1951 \\
1952 \\
1953 \\
1954 \\
1955\end{array}$ & $\begin{array}{l}138 \\
144 \\
143 \\
146 \\
146\end{array}$ & $\begin{array}{l}57 \\
59 \\
57 \\
56 \\
58\end{array}$ & $\begin{array}{l}49 \\
48 \\
45 \\
44 \\
42\end{array}$ & $\begin{array}{l}244 \\
251 \\
245 \\
246 \\
246\end{array}$ & $\begin{array}{l}96 \\
99 \\
97 \\
98 \\
98\end{array}$ & $\begin{array}{l}123 \\
125 \\
120 \\
119 \\
119\end{array}$ \\
\hline $\begin{array}{l}1956 \\
1957 \\
1958 \\
1959 \\
1960\end{array}$ & $\begin{array}{l}146 \\
146 \\
140 \\
145 \\
144\end{array}$ & $\begin{array}{l}58 \\
56 \\
52 \\
55 \\
55\end{array}$ & $\begin{array}{l}41 \\
40 \\
37 \\
37 \\
36\end{array}$ & $\begin{array}{l}245 \\
242 \\
229 \\
237 \\
235\end{array}$ & $\begin{array}{l}97 \\
96 \\
91 \\
94 \\
93\end{array}$ & $\begin{array}{l}118 \\
115 \\
108 \\
111 \\
109\end{array}$ \\
\hline $\begin{array}{l}1961 \\
1962 \\
1963 \\
1964 \\
1965\end{array}$ & $\begin{array}{l}143 \\
143 \\
145 \\
142 \\
136\end{array}$ & $\begin{array}{l}54 \\
53 \\
52 \\
51 \\
48\end{array}$ & $\begin{array}{l}37 \\
35 \\
36 \\
34 \\
33\end{array}$ & $\begin{array}{l}234 \\
231 \\
233 \\
227 \\
217\end{array}$ & $\begin{array}{l}93 \\
92 \\
92 \\
90 \\
86\end{array}$ & $\begin{array}{l}109 \\
108 \\
109 \\
107 \\
103\end{array}$ \\
\hline
\end{tabular}

(a) The rates have been computed by relating the number of children born in each 1 -year duration group to 100 initial marriages of the corresponding marriage cohort. The number of births includes only legitimate live births. (See Strömmer, Recent demographic developments and population policies in Finland. Population Index. Vol. 22, 1 (Jan. 1956).

future, it is important to observe that the decline in marital fertility for the country as a whole appears to be ending (Table B). The high proportion of marriages in the post-war period has been stabilized by the fact that the proportion of married people in the young ageclasses has continued to rise (Fig. 6).

The intrinsic rate of natural increase declined during the phase ending in the 1930 's, when in fact even negative values appeared. This was due to a decline both in the proportion of married people and in marital fertility. This rate has declined from its post-war peak, but at the end of the period it was still 6-7 pro mille, which is close to the level maintained before the development following the demographic threshold began to produce radical changes in the population structure. The decline in mortality has of course contributed to the increasing growth tendency. Above all, however, it is due to the increasing proportion of the married, the growing willingness to start a family. This phenome- 
non, as the swonder of the post-war demographic development in Finland, evidently deserves more attention from Finnish social scientists than it has received.

In 1870 there were 33 towns in Finland, and their joint population was 132,000 or $7.5 \%$ of the population of the whole country. These towns were small in size; only three of them had more than 10,000 inhabitants, though Helsinki had almost 30,000 . In 1965 a population over $2,000,000$ $-44.3 \%$ of the entire population - was living in urban communes - towns and market towns. The number of towns has risen to 70 , of which 44 had over 10,000 inhabitants. The population of the capital was 506,000 .

The general picture of the demographic transition in the country-side, as sketched by the crude rates of demographic change is more or less consistent with the overall picture described above (graphic appendix I and II) ${ }^{1}$ This is understandable in view of the relative numerical strength

1 Graphic appendix I describes the crude birth and death rates, graphic appendix II the crude rate of natural increase in various commune groups and regions, 1870-1965. As to the regions, see Fig. 1. of rural and urban population up to recently. The general picture of demographic transition in the cities, on the other hand, has characteristics of its own, and the typical features of the transition are more prominent here.

After the decline of the crude death rate following the famine years of 186668 , the crude birth rate in the cities actually rose in the beginning. As a consequence, the crude rate of natural increase was reinforced; before the demographic threshold around 1910 it was double that of the 1870 's. With the sharp decline in the crude birth rate of the urban population, natural increase had ceased almost altogether by the 1930's. After the Second World War, as a consequence of an even more abrupt upward turn in the crude birth rate, it became fixed at 10 pro mille, the original level from which it had started to decline with the lowering of the crude birth rate.

The gap between the birth rate of rural and urban populations became even wider with the transition development up to the 1920 's. After that the gap shrank rapidly, to such an extent that at the end of the period (1965) the crude birth rate in the cities was higher than in the country (Table C). Actually, fertility in rural areas continued to be higher, but the

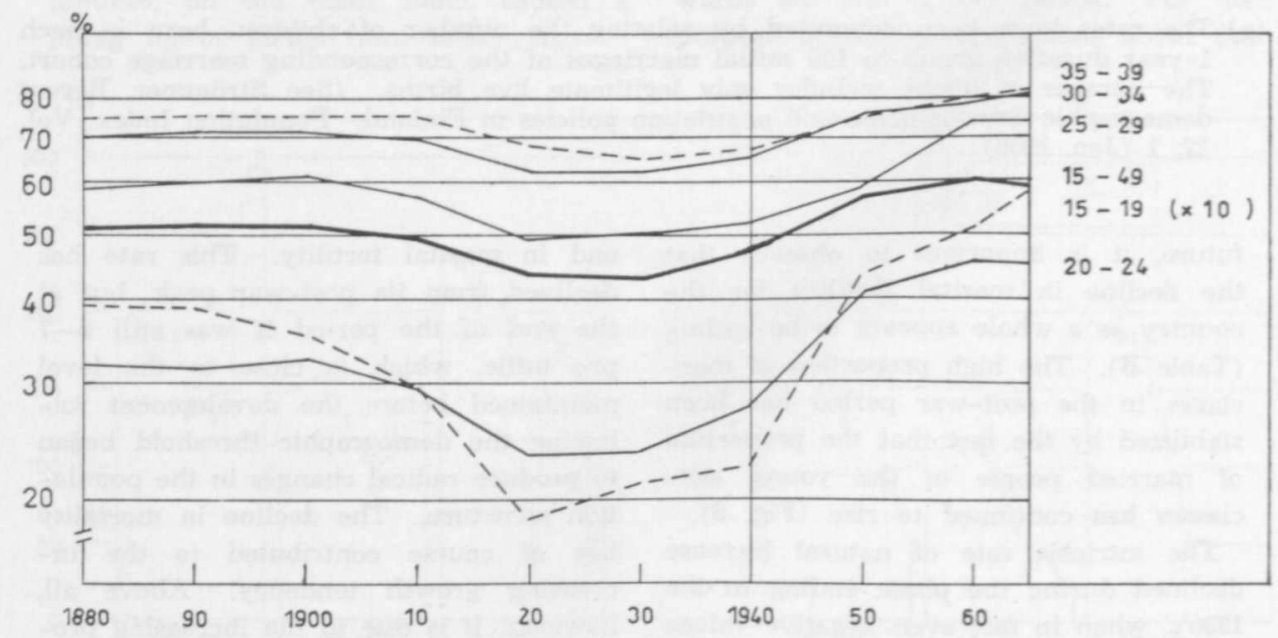

Figure 6. The percentage of married women in selected groups of child-bearing age for period $1880-1965$ (log. scale). 
Table C. Fertility and mortality differences between urban and rural populations, 1871-75 and 1961-65.

\begin{tabular}{|c|c|c|c|c|}
\hline \multirow{4}{*}{ Rates } & \multirow{4}{*}{$\begin{array}{c}\text { Period } \\
2 \\
\end{array}$} & Urban (a) & \multicolumn{2}{|c|}{ Rural } \\
\hline & & \multicolumn{3}{|c|}{ communes } \\
\hline & & \multicolumn{2}{|c|}{ rate } & \multirow{2}{*}{$\begin{array}{c}\text { urban com- } \\
\text { munes }=100 \\
5\end{array}$} \\
\hline & & 3 & 4 & \\
\hline Crude birth rate & $\begin{array}{l}1871-75 \\
1961-65\end{array}$ & $\begin{array}{l}28.6 \\
19.1\end{array}$ & $\begin{array}{l}37.7 \\
16.9\end{array}$ & $\begin{array}{r}132 \\
88\end{array}$ \\
\hline General fertility rate & $\begin{array}{l}1871-75 \\
1961-65\end{array}$ & $\begin{array}{l}92.0 \\
69.3\end{array}$ & $\begin{array}{r}146.2 \\
74.7\end{array}$ & $\begin{array}{l}159 \\
108\end{array}$ \\
\hline Legitimate f. r. (b) & $\begin{array}{l}1871-75 \\
1961-65\end{array}$ & $\begin{array}{l}222.0 \\
112.2\end{array}$ & $\begin{array}{l}270.3 \\
117.3\end{array}$ & $\begin{array}{l}122 \\
105\end{array}$ \\
\hline Illegitimate f. r. (b) & $\begin{array}{l}1871-75 \\
1961-65\end{array}$ & $\begin{array}{r}19.5 \\
8.3\end{array}$ & $\begin{array}{r}23.8 \\
7.1\end{array}$ & $\begin{array}{r}122 \\
86\end{array}$ \\
\hline Crude death rate & $\begin{array}{l}1871-75 \\
1961-65\end{array}$ & $\begin{array}{r}23.8 \\
8.8\end{array}$ & $\begin{array}{r}21.5 \\
9.8\end{array}$ & $\begin{array}{r}90 \\
111\end{array}$ \\
\hline Infant mortality rate & $\begin{array}{l}1871-75 \\
1961-65\end{array}$ & $\begin{array}{r}211.7 \\
18.3\end{array}$ & $\begin{array}{r}167.6 \\
19.3\end{array}$ & $\begin{array}{r}79 \\
105\end{array}$ \\
\hline Standardized death rate & $\begin{array}{l}1871-75 \\
1961-65\end{array}$ & $\begin{array}{r}27.5 \\
9.5\end{array}$ & $\begin{array}{r}21.3 \\
9.3\end{array}$ & $\begin{array}{l}77 \\
98\end{array}$ \\
\hline
\end{tabular}

(a) Towns and market towns.

(b) The number of legitimate (illegitimate) children born to 1000 married (non-married) women in age groups of 15 to 49 years.

margin was not large; while in $1871-75$ the legitimate fertility rate was $22 \%$ higher in rural than in urban areas, in $1961-65$ the difference was only $5 \%$.

A closer analysis of mortality shows that the higher crude death rate of rural than of urban populations (a difference of $11 \%$ ) is also due to differences in demographic structure. The standardized death rate during $1961-65$ was practically the same for both population groups, whereas during $1871-75$ it was almost one fourth smaller in the country than in the city.

We may add to the discussion of natural growth that although by 1965 the crude rate of natural increase had become higher in the cities than in the country (the relevant figures are 10.3 and 7.1 pro mille respectively for the period $1961-65$ ), the growth potential was still on the average higher in rural than in urban communes due to higher fertility.
The relative population proportions of the various regions of the country are considerably changed now at the beginning of the last third of the 20th century from what they were at the beginning of the demographic transition one hundred years ago. The population of the "Industrial Finland " of today (regions $1,3-7)$ in 1870 was 730,000 , which was $46 \%$ of the whole population. The joint population of the intermediate areas (2, 8-13) was somewhat larger: 740,000 inhabitants, or about $47 \%$. The population of the three northernmost areas (14 -16) was only 116,000 , or about $7 \%$ of the total population. By 1965, the lastmentioned figure had risen to 511,000 , which was $11 \%$ of the total, while the population of the southernmost industrial areas was $2,615,000-57 \%$. The population of the intermediate areas had risen more slowly, and was now $1,500,000$, corresponding to only $32 \%$ of the total population. 
In addition to migration, these differences in development have also been caused in part by the natural growth of the population; in other words, by differences of transitional levels and timing among the various regions. These differences have been studied here mainly by means of crude analysis based on the crude rates of birth, death and natural increase.

The crude death rate, before the transition period, was highest in the southern and south-west regions, which on many accounts can be considered the most advanced area of Finnish society of one hundred years ago. Already during the last decades of the 19th century, the death rate declined in these regions faster than elsewhere, so that at the turn of the century (1901-05) they had almost without exception a lower crude death rate than average. Three decades later (1931$35)$ the situation was the same. Thereafter, however, the crude death rate has declined more sharply in the northermost regions. Thus the situation has been reversed, and the lowest rates are now to be found in the under-developed regions of the north (Table D, col. 5).

A comparison of the standardized death rates shows that the present reversal compared to the earlier situation is in fact due to factors of population structure. The southern and southwestern regions are still in the most favorable position. A comparison of the standardized and crude death rates for 1964-65 shows that structural factors have favored the northernmost areas by $2-3$ promille units, while in the south the distortion in the opposite direction caused by these factors is in one case (Region 2) almost of the same order of magnitude (Col. 7). Inter-regional differences turn out to be actually fairly limited: the range of variation of the crude death rate was 6.9-11.6 pro mille, that of the standardized death rate $8.7-10.8$ pro mille.

The extent to which male mortality outweighs female in Finland has often been commented upon (cf. Table A, cols. $5-6)$. The regional life tables published by the Central Statistical Office for the years $1961-65$ show that this difference is larger than average in the province of Uusimaa, as well as in the south-eastern and northern areas. Male mortality is highest of all in North Carelia (Region 9), although there female mortality is also higher than elsewhere. In a comparison with the rest of Scandinavia, it appears that this area has the highest male mortality not only in all of Finland but at the same time in all of Scandinavia.

The most important observations concerning the transitional development of the crude birth rate up to the great demographic threshold concern, on the one hand, the outright rise or very slight fall of the birth rate in the south-east, and on the other hand its sharp decline in the provinces more affected by emigration (Regions 11-15:. The same dichotomy for the country as a whole concerning the birth rate as for the death rate had become evident by the trough years of $1931-35$. In the southern regions the decline was so much more rapid than elsewhere that they formed a continuous regional zone. Especially in Uusimaa, where the capital of the country is located, the fall was sharp; in three decades the crude birth rate fell off by almost one third.

Uusimaa differs from the rest of the country also for the last period, 1931 35-1961/65. In all other areas the postwar fertility wave, bringing with it the large age-classes, had levelled off, and the crude birth rate had reached and even gone beyond the low of the early thirties. In Uusimaa, however, it became stable already in the early fifties at a level which ten years later corresponded to the average for the whole country (Graphic appendix I). Only in the northern areas were the birth rates higher than for Uusimaa.

The marital fertility rate (Table $\mathrm{D}$, cols. 8-11), which eliminates the effect of structural differences, is not higher in Uusimaa than in the other southern areas. But it is interesting to observe that the matiral fertility rate for Uusimaa 


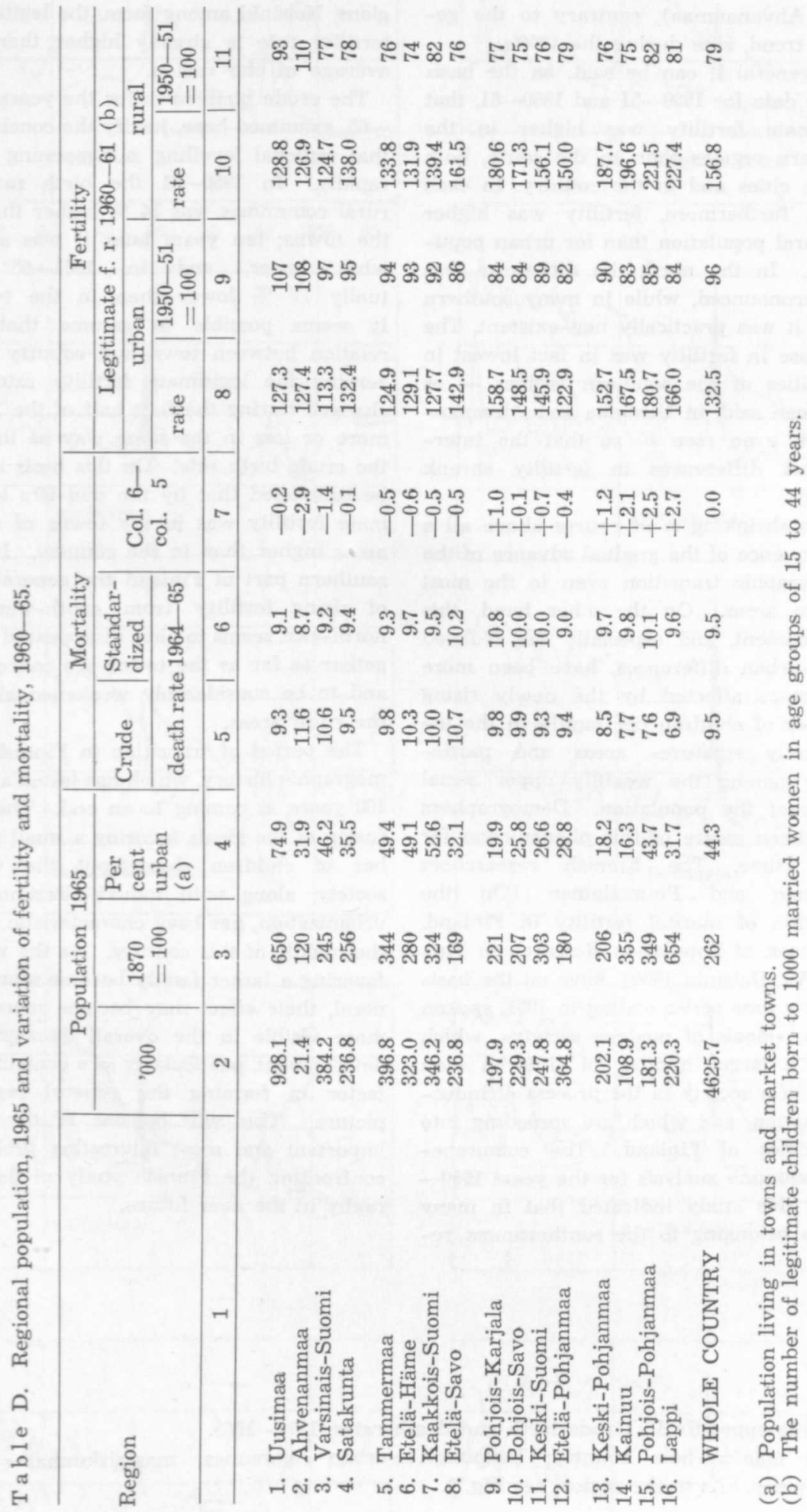


(and Ahvenanmaa), contrary to the general trend, rose during the 1950's.

In general it can be said, on the basis of the data for $1950-51$ and $1960-61$, that legitimate fertility was higher in the northern regions than in the south, both in the cities and in the country. In each areas, furthermore, fertility was higher for rural population than for urban population. In the north the difference was still pronounced, while in many southern areas it was practically non-existent. The decrease in fertility was in fact lowest in the cities of the southern regions - as has been said, in Uusimaa and Ahvenanmaa it even rose - so that the interregional differences in fertility shrank rapidly.

This shrinking is of course above all a consequence of the gradual advance of the demographic transition even to the most remote areas. On the other hand, this development, and especially the reduced rural-urban differences, have been more and more affected by the newly rising number of children per family in the industrially >mature, areas and particularly among the wealthy upper social layers of the population. Demographers have been aware of this phenomenon for some time. The Finnish researchers Hartman and Puumalainen (On the variation of marital fertility in Finland. Yearbook of Population Research in Finland VI. Helsinki 1960), have on the basis of their time series ending in 1951, spoken of the sideals of modern societys, which favor a larger number of children than those of a society in the process of industrialization, and which are spreading into the cities of Finland. The communeby-commune analysis for the years 1960 61 in this study indicated that in many towns belonging to the southernmost re- gions, Helsinki among them, the legitimate fertility rate is already higher than the average of the region.

The crude birth rates for the years 1964 -65 , examined here, justify the conclusion that regional levelling is happening very rapidly. In $1950-51$ the birth rate in rural communes was $14 \%$ higher than in the towns; ten years later it was somewhat lower, and in $1964-65$ actually $17 \%$ lower than in the towns. It seems possible to assume that the relation between town and country concerning the legitimate fertility rate has changed during the first half of the 1960's more or less in the same way as that of the crude birth rate. On this basis it can be concluded that by the mid- 60 's legitimate fertility was in the towns of many areas higher than in the country. In the southern part of Finland the general line of rising fertility from south-west to north-east seems to have disappeared altogether as far as the towns are concerned, and to be considerably weakened also in the rural areas.

The period of transition in Finnish demographic history, which has lasted almost 100 years, is coming to an end. The diffusion of the ideals favoring a small number of children throughout the whole society, along with industrialization and urbanization, has been characteristic up to the middle of this century. As the values favoring a larger family become more general, their effect may become more and more visible in the overall demographic development, particularly as a contributing factor in forming the general regional picture. This will be one of the most important and most interesting problems confronting the Finnish study of demography in the near future.

Graphic appendix I. Crude birth and death rates, 1870-1965.

Koko $\operatorname{maa}=$ whole country; kaupungit $=$ urban communes; maalaiskunnat $=$ rural communes. As to the region, see Fig. 1. 

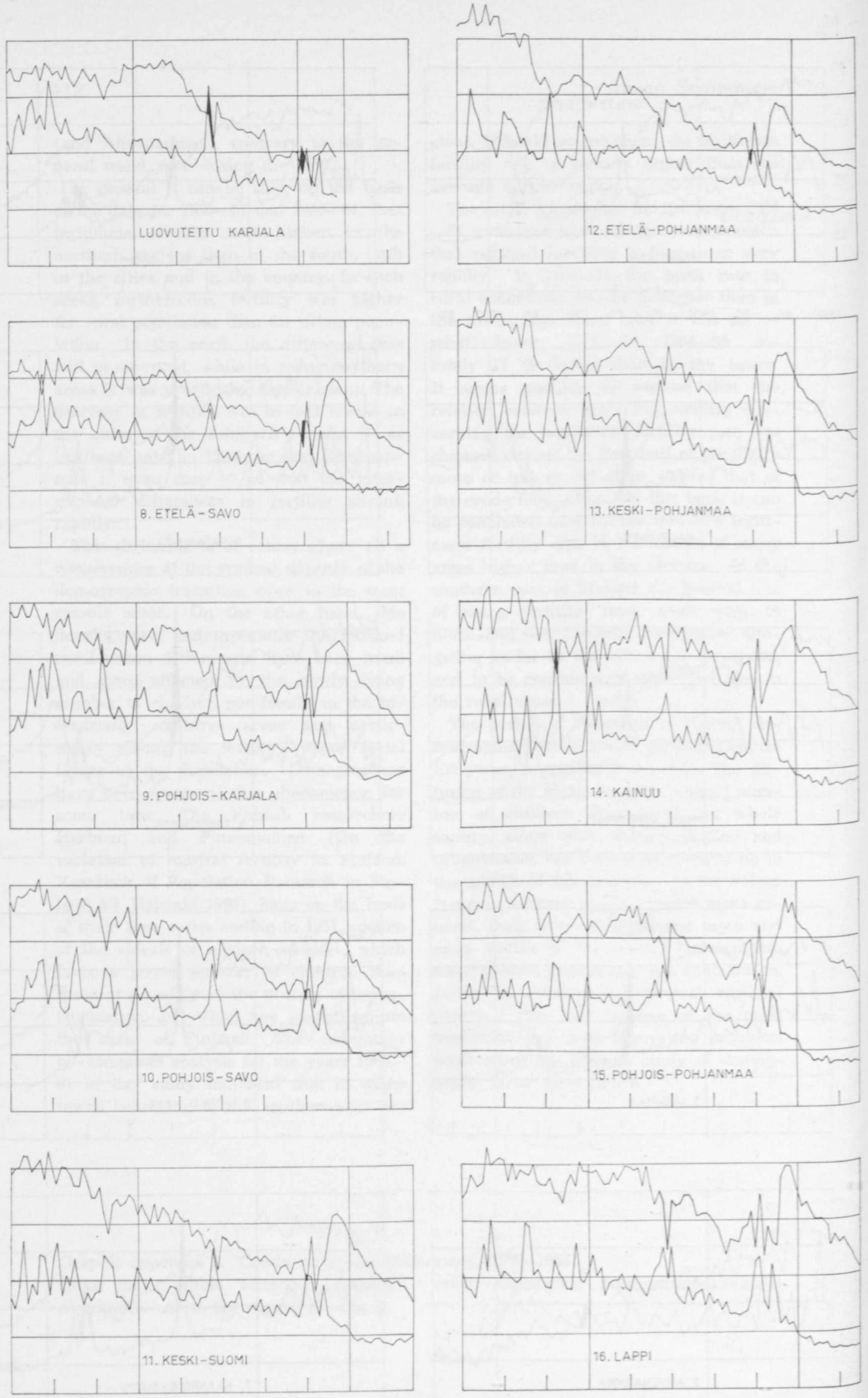

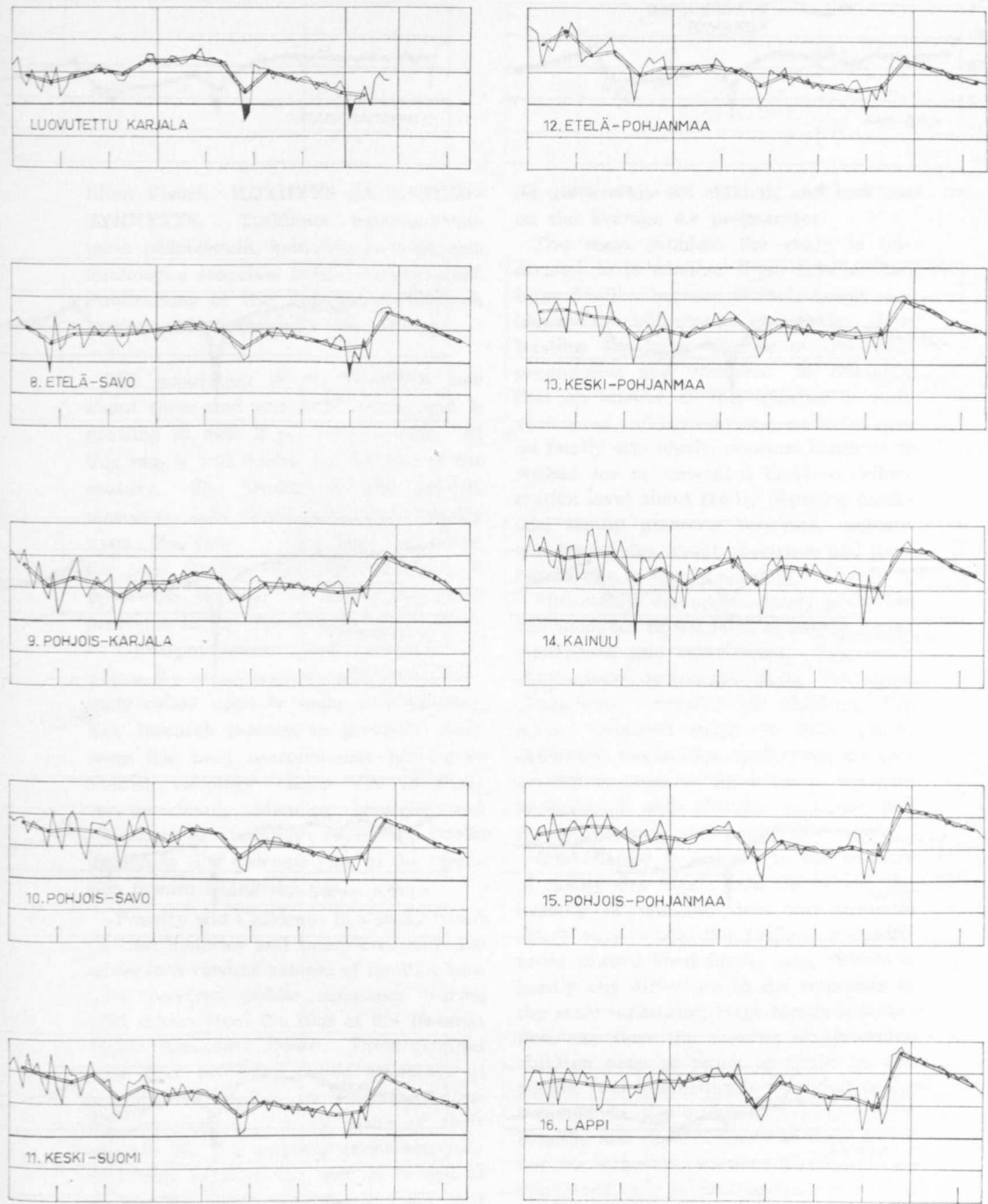

Graphic appendix II. Crude rate of natural increase, 1870-1965.

Koko maa $=$ whole conutry; kaupungit $=$ urban communes; maalaiskunnat $=$ rural communes. As to the regions, see Fig. 1. 
$\%$

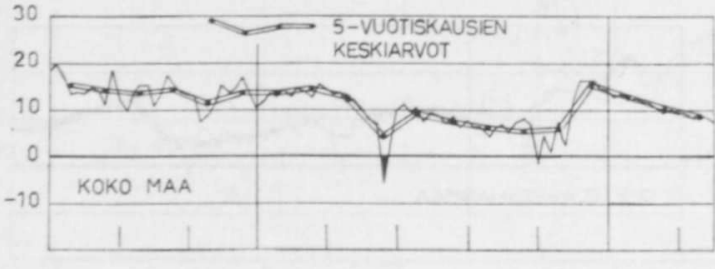

$\begin{array}{llllllllll}1870 & 80 & 90 & 1900 & 10 & 20 & 30 & 40 & 1950 & 60\end{array}$
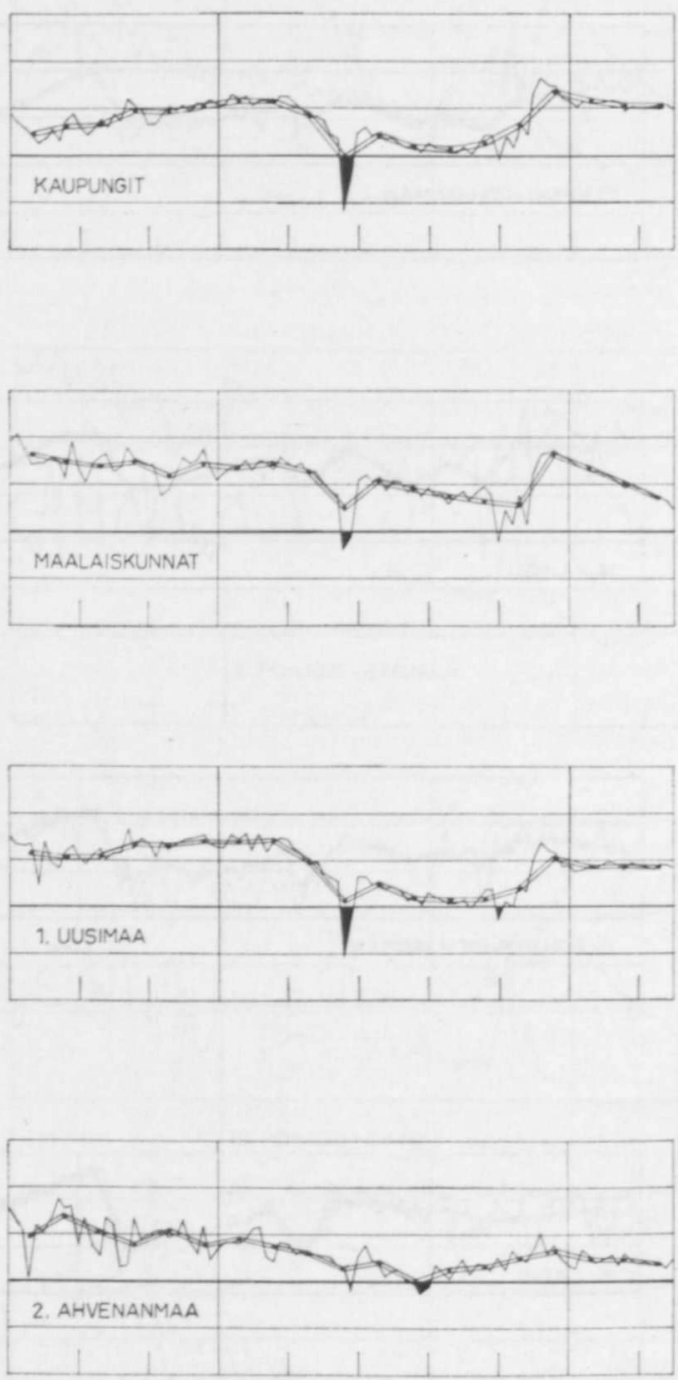
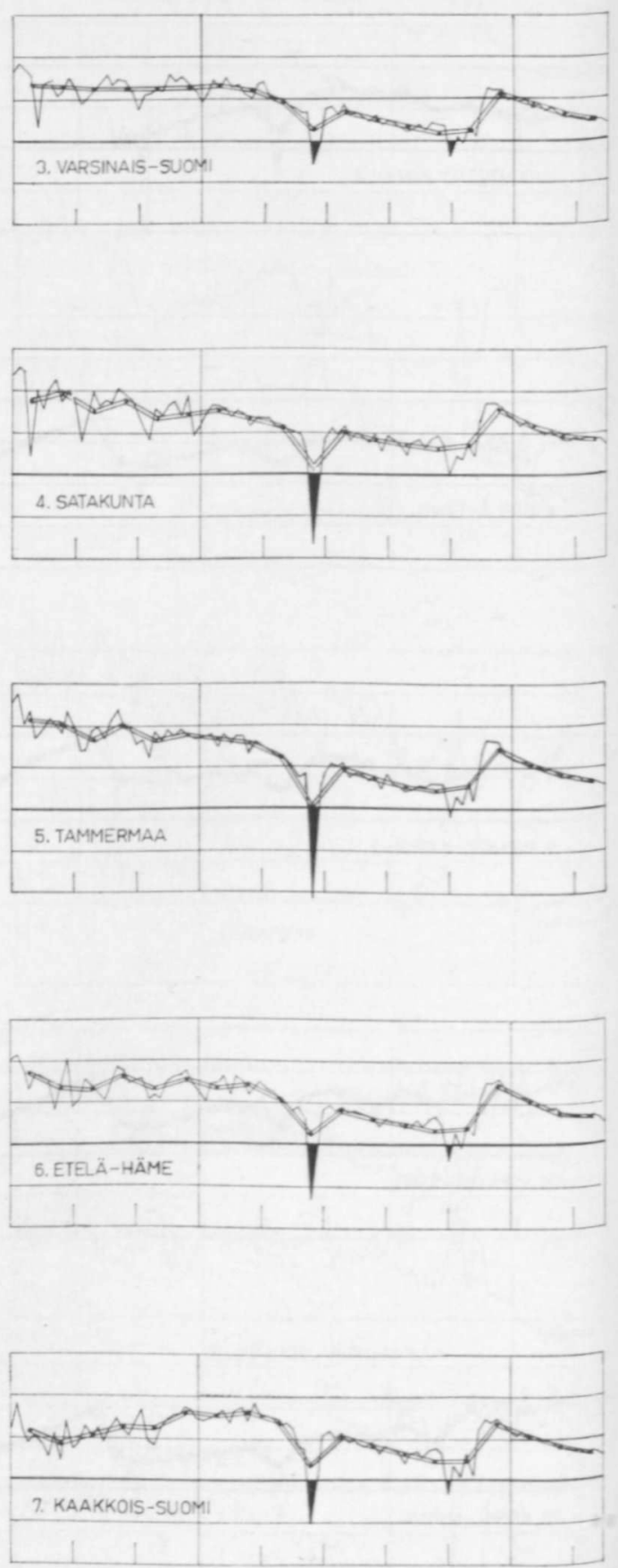